\title{
NO $_{2}$ CONCENTRATION IN BANEPA VALLEY, NEPAL
}

\author{
${ }^{1}$ Ahmad Kamruzzaman Majumder*, ${ }^{2}$ V. Krishna Murthy, ${ }^{3}$ Sanjay Nath Khanal, \\ ${ }^{4}$ Dhiraj Giri \\ ${ }^{1,3}$ Department of Environmental Science and Engineering, Kathmandu University, P.O. \\ Box 6250, Kathmandu, Nepal. \\ ${ }^{2}$ Department of Chemistry, PES Institute of Technology, Bangalore, India \\ ${ }^{4}$ Department of Natural Science, Kathmandu University, Kathmandu, Nepal. \\ *Corresponding author: kamrul_sub@hotmail.com \\ Received 2 August; Revised 23 September
}

\begin{abstract}
This study comprised of air quality monitoring during the day time at three municipalities of Banepa, Dhulikhel and Panauti(Known as Banepa Valley) in Kavre district of Nepal. The study was conducted in order to establish a baseline air quality data for those municipalities as the first time ever in the district. In each of those municipalities three air monitoring stations were established representing predominant industrial, commercial and residential areas. Nitrogen Dioxide $\left(\mathrm{NO}_{2}\right)$ had been estimated from air sampling programme which spanned 7 months and a total of 126 days reflecting winter, premonsoon and monsoon seasons. Low Volume Air (LVA) Sampler and Personal air sampler were used for sampling. UV spectrophotometer was used for estimation of the $\mathrm{NO}_{2}$. The study found that during winter season the concentration of $\mathrm{NO}_{2}$ was more and among the areas commercial area found to be highest level pollution. The over all mean, minimum and maximum level of $\mathrm{NO}_{2}$ was found to be $24.62 \mu \mathrm{g} / \mathrm{m}^{3}, 11.26 \mu \mathrm{g} / \mathrm{m}^{3}$, $91.20 \mu \mathrm{g} / \mathrm{m}^{3}$ in the Banepa valley. The seasonal trend in pollution levels show that winter > pre-monsoon $>$ monsoon. The pollution concentration trend noted among the areas was commercial $>$ industrial $>$ residential on almost all the occasions. This finding conclude that, most of the time $\mathrm{NO}_{2}$ level are below the National Ambient Air Quality Standards (NAAQS) and World Health Organization (WHO) guideline representing little risk at present in Banepa Valley however commercial area of Banepa is more polluted and is associated with higher $\mathrm{NO}_{2}$ concentration compared to other areas.
\end{abstract}

Keywords: $\mathrm{NO}_{2}$, Nepal, Banepa, air quality, personal air sampler

\section{INTRODUCTION}

Nepal, a relatively small country with $1,47,181 \mathrm{sq} \mathrm{km}$ area inhabited by 22 million people, is known for exquisite environment. However, the real scenario is quite different because urban areas are environmentally degrading due to rapid unplanned urbanization and industrialization. Increasing numbers of human population, industries and automobiles, decreasing agricultural productivity, the frequent occurrence of floods in the lowlands, landslides in the midlands and forest fire are major environmental issues, and recent studies reveal that even the glorious mountain peaks of the high Himalayas have also undergone incipient pollution (Dokiya et al., 1992; Shrestha et al., 1997). Air pollution is considered to be one of the serious and prominent types of environmental pollution that is prevalent in most industrial towns and cosmopolitan cities of the world. It had been a 
general impression in the past that air pollution is exclusively a problem of the industrially developed nations, however, recent studies have shown that air pollution is a growing problem in developing countries as well, and therefore, attention should be paid to this issue before it is too late. (Shrestha et al., 1997). Increased awareness of health problems related to air pollution arising from urbanization and industrialization has, especially during the last two centuries, gradually created a demand for more efficient emission controls, and thus there has been a notable decrease in both the emissions and ambient concentrations of many air pollutants. The health effect includes increased mortality and aggravation of existing respiratory and cardiovascular disease, as evidenced by increased hospitalization. Thapa (2001) concluded that the concentrations of pollutants (biological and non-biological) in the air have increased as the urbanization proceeded in Kathmandu. The level of these pollutants has exceeded the standards set by EPA and WHO. Operation of brick kilns has been considered as one of the major source of air pollution in the Kathmandu Valley. Brick manufacturing by Bull's Trench kilns was potentially a significant source of atmospheric emission in Nepal (Sharma et al., 1995).

Again meteorological conditions affect ambient air pollution in numerous ways. The most important role of meteorology is in the dispersion, transformation and removal of air pollutants from the atmosphere. There are numerous meteorological variables, often interrelated, that can affect ambient air pollution levels. Study of the relationship of air pollution and individual meteorological variables may be misleading as it does not account for the interrelation between the variables, while air pollutant levels normally respond to all of meteorological variables representing an air mass. Dry winter periods are the most vulnerable to air pollution while during the rainy season air pollutants are well below the average annual value as the rain flushes pollutants from the air.

From the above discussion it can be said that most of the air pollution studies conducted in Nepal were focused on Kathmandu Valley only. Very few air pollution study were done in semi urban areas of the country. The majority of the air pollution studies focused on traffic emissions, whereas industrial, domestic and other sources of air pollutants are not seriously undertaken in Nepal. There are several Non Governmental Organizations (NGOs), government offices and institutes working in the field of air pollution. However, their activities are scattered and limited within the city areas. At this point it is need to note that, so far there were no air quality monitoring programme conducted in Banepa, Dhulikhel or Panauti municipalities which can be considered as an semi-urban area..

\section{Objectives}

The main objective of this study was to observe the variation of $\mathrm{NO}_{2}$ concentration in sub-urban areas of Banepa valley. It also aimed to assess the variation of $\mathrm{NO}_{2}$ concentrations at different seasons in different predominant land use areas like industrial, commercial and residential areas.

\section{MATERIALS AND METHODS Site Description}

Banepa, Dhulikhel and Panauti are geographically located in the same valley region known as the Banepa valley (Figure 1) with distances of no more than 7 to $8 \mathrm{~km}$ in between them (Table 1). Banepa and Dhulikhel are both situated on the Arniko Highway. This highway is Nepal's only road to the Tibetan border and was constructed in the 1960s by the Chinese. It is an important trade route for goods coming from China into Nepal. 
Panauti is attainable from the Arniko Highway in Banepa over a seven kilometer long side street. The study comprised of air monitoring during the day time at three municipalities of Banepa, Dhulikhel and Panauti. In each of the Municipalities three air monitoring stations were established representing predominant Industrial, Commercial and Residential areas. So there were altogether 9 air sampling stations selected in Banepa Valley, they were given below:

Table 1. General information about study area

\begin{tabular}{|l|c|c|c|}
\hline Municipalities & $\begin{array}{c}\text { Distance from } \\
\text { Banepa }\end{array}$ & $\begin{array}{c}\text { Number of } \\
\text { monitoring } \\
\text { sites }\end{array}$ & $\begin{array}{c}\text { Area (sq. } \\
\mathbf{~ k m ) ~}\end{array}$ \\
\hline Banepa & $0 \mathrm{~km}$ & 3 & 5.56 \\
\hline Dhulikhal & $4 \mathrm{~km}$ & 3 & 8.22 \\
\hline Panauti & $5.5 \mathrm{~km}$ & 3 & 19.71 \\
\hline Total & - & 9 & 33.49 \\
\hline
\end{tabular}

\section{Sampling Time and Frequency}

$\mathrm{NO}_{2}$ has been estimated from air sampling programme which spanned 7 months and a total of 63 days from a height of one meter from the ground. The samples were collected twice in a month for each of the nine sites. Every day two samples were collected in the morning and evening. So the total number of sample was 126 . The total sampling time was 8 hours in a day. These 8 hours in a day were divided into 4 hours each covering pick hours of day $9 \mathrm{am}$ to $5 \mathrm{pm}$. So actual period of high traffic concentration of pollutants was measured.

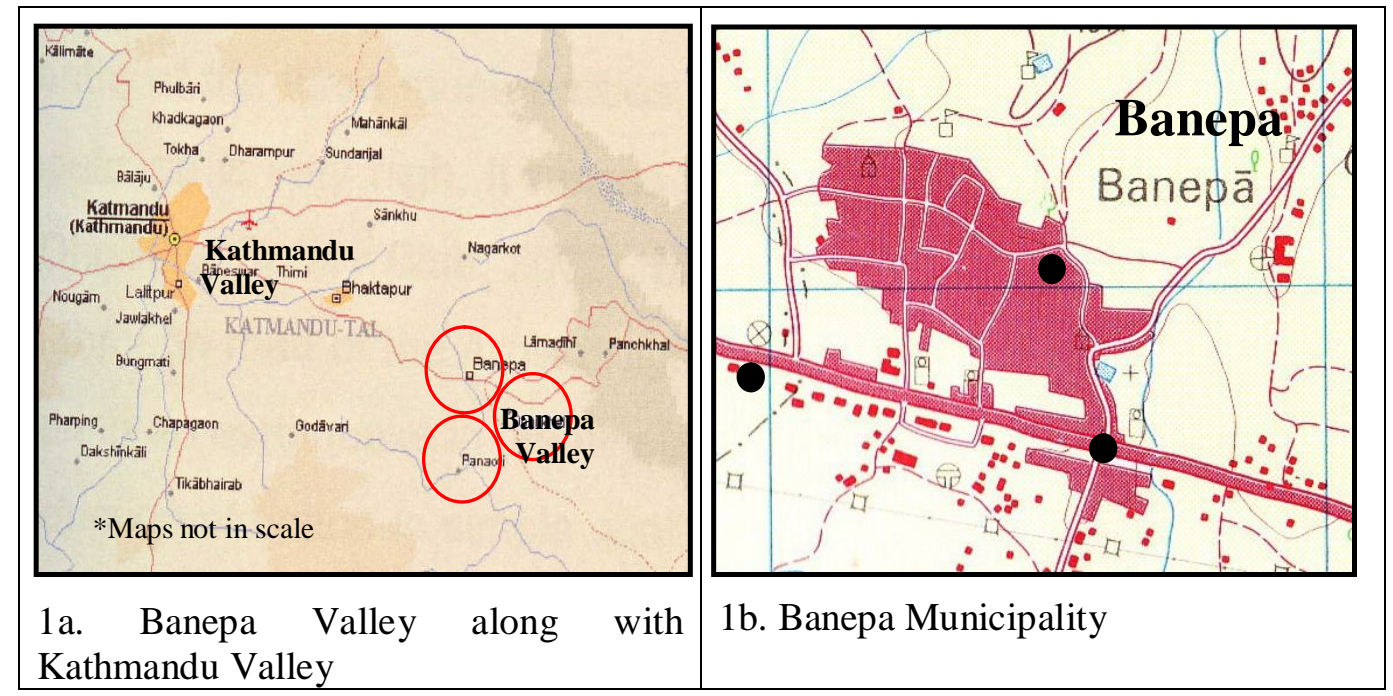




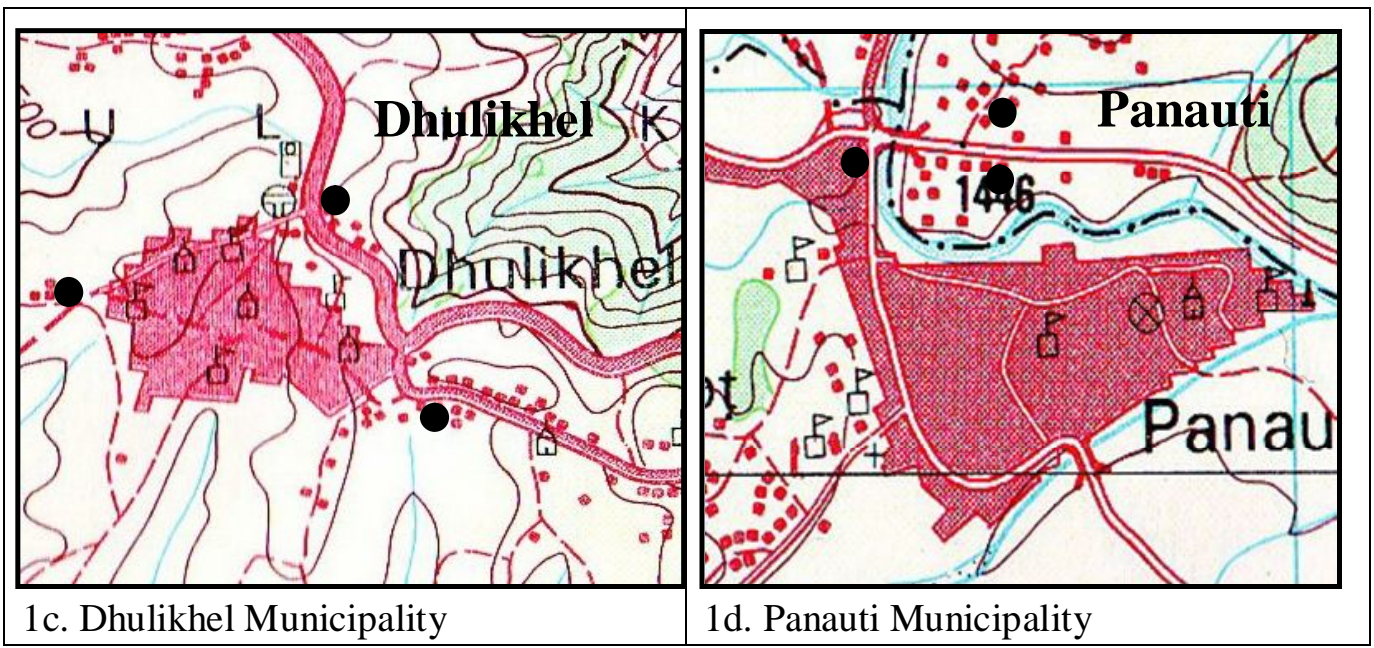

Figure 1. Showing the study area (Black dots indicate monitoring sites)

\section{Sampling Methods}

Personnel air sampling method, which represents subjective exposures to ambient air pollutants, was followed using standard Personal Monitors. The equipment, known as personnel air sampler used for $\mathrm{NO}_{2}$ monitoring was standard dust/gas sampler (M/s. SKC, U.S.A.). It was designed for the measurement of dust and gaseous pollutant in the work environment. A low volume air sampling assembly was also employed to carryout the $\mathrm{NO}_{2}$ sampling. Sodium hydroxide is used for $\mathrm{NO}_{2}$ as absorbent medias. UV spectrophotometer was used for estimation of the $\mathrm{NO}_{2}$.

\section{Estimation of $\mathrm{NO}_{2}$}

Nitrogen dioxide is absorbed in sodium hydroxide absorbing medium to form a stable solution sodium nitrate. The diazonium salt formed on the addition of sulphanilic acid is coupled with $\mathrm{N}$-(1-napthyl) ethylenediamine to form a colored azo dye. For the estimation of $\mathrm{NO}_{2} \mathrm{Jacob}$ and Hochheiser (Modified) Method was used. All the solutions forming pink colored azo dye of different concentration gives different color and from the colorimetric method which is built on the Beer- Lambert's law states that high color indicates higher concentration. These solutions giving different color were put in the spectrophotometer (UV-Visible Spectrophotometer-1601) with the wavelength of $540 \mathrm{~nm}$ and the absorbance is noted. On the basis of concentration and absorbance data the calibration curve was made. With the help of this calibration curve the concentration of $\mathrm{NO}_{2}$ in air was collected.

\section{RESULTS AND DISCUSSION}

\section{Mean concentration of $\mathrm{NO}_{2}$ in Banepa Municipality}

The seasonal mean values according to commercial, industrial and residential areas of Banepa Municipality are presented in Figure 2. The findings suggest that during winter season the $\mathrm{NO}_{2}$ was more. Among the areas commercial area in Banepa noted highest $\mathrm{NO}_{2}$ level. In fact, at commercial area a the mean concentration was found to be 62.90 $\mu \mathrm{g} / \mathrm{m}^{3}$ in the winter and a maximal level of $91.20 \mu \mathrm{g} / \mathrm{m}^{3}$ has been recorded on one occasion in winter which was not very much deviant to the mean level indicating persistently higher levels of $\mathrm{NO}_{2}$ in this area. The over all mean, standard deviation, 
minimum and maximum level of $\mathrm{NO}_{2}$ in Banepa was respectively $29.88 \mu \mathrm{g} / \mathrm{m}^{3}$, $14.25 \mu \mathrm{g} / \mathrm{m}^{3}, 13.37 \mu \mathrm{g} / \mathrm{m}^{3}$ and $91.20 \mu \mathrm{g} / \mathrm{m}^{3}$.

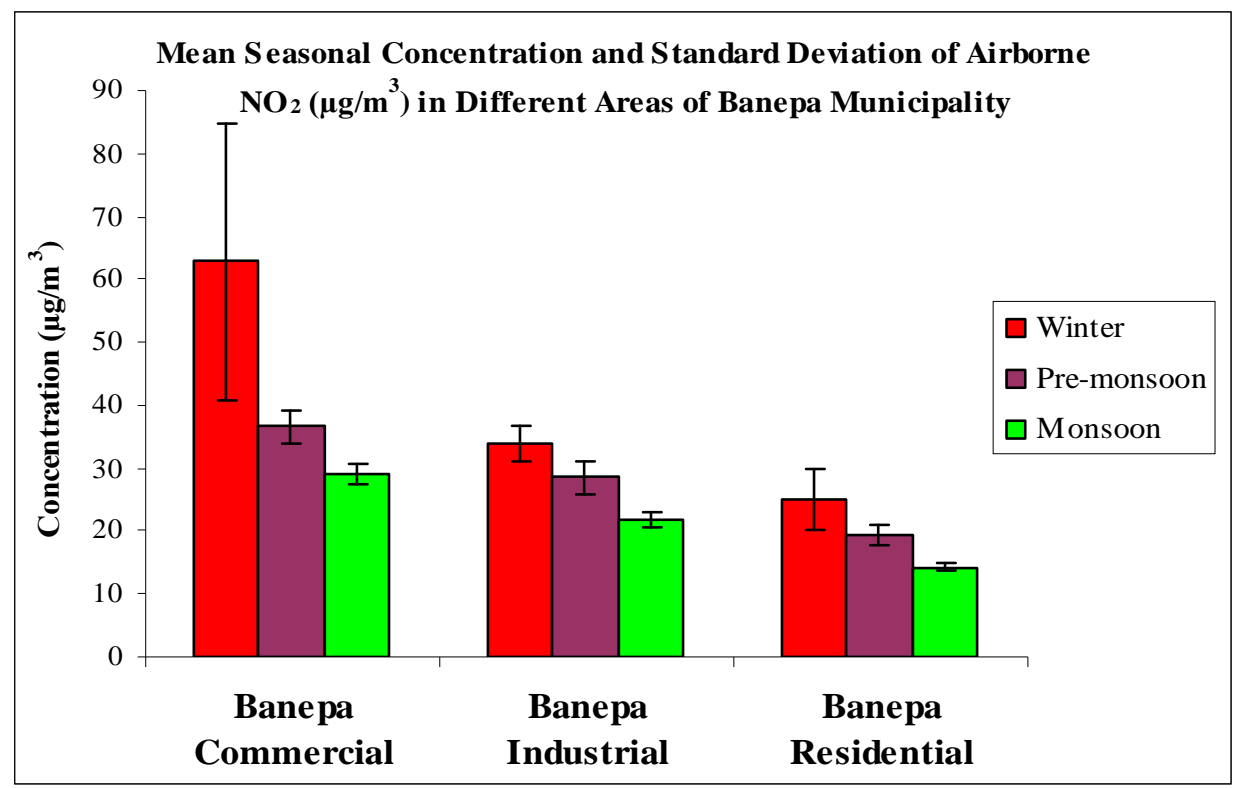

Figure 2. Mean seasonal concentration and standard deviation of airborne $\mathrm{NO}_{2}$ in different areas of Banepa municipality.

The National Ambient Air Quality Standards (NAAQS) in Nepal for $\mathrm{NO}_{2}$ had been set as $80 \mu \mathrm{g} / \mathrm{m}^{3}$ which is 24 hourly values, $40 \mu \mathrm{g} / \mathrm{m}^{3}$ for annual averaging. From the Figure 2 it was seen that only the concentration of mean $\mathrm{NO}_{2}$ pollution in Banepa Industrial area had crossed the NAAQS level in winter season, all other sites are with in the permissible limit. But, it should be note that the present study represented 8 hourly mean values which were reflected only the pick hours concentration of $\mathrm{NO}_{2}$ in the studied areas. The seasonal trend in $\mathrm{NO}_{2}$ levels show that winter>pre-monsoon $>$ monsoon. The trend noted among the areas was commercial>industrial>residential on all the occasions. This finding suggests that commercial area of Banepa is more defined and is associated with higher $\mathrm{NO}_{2}$ concentration compared to industrial area.

\section{Mean concentration of $\mathrm{NO}_{2}$ in Dhulikhel Municipality}

The seasonal mean values according to commercial, industrial and residential areas of Dhulikhel Municipality are presented in Figure 3. From the study it is found that during winter season the $\mathrm{NO}_{2}$ was more and among the areas Dhulikhel commercial area noted highest mean $\mathrm{NO}_{2}$ concentration with a mean concentration of $24.09 \mu \mathrm{g} / \mathrm{m}^{3}$. But at industrial area a maximal level of $35.25 \mu \mathrm{g} / \mathrm{m}^{3}$ has been recorded on one occasion, which was highest within the areas. The over all mean, standard deviation, minimum and maximum level of $\mathrm{NO}_{2}$ in Dhulikhel municipality was respectively $21.32 \mu \mathrm{g} / \mathrm{m}^{3}$, $5.81 \mu \mathrm{g} / \mathrm{m}^{3}, 11.26 \mu \mathrm{g} / \mathrm{m}^{3}$ and $35.25 \mu \mathrm{g} / \mathrm{m}^{3}$. From the study it was also seen that the concentration of mean $\mathrm{NO}_{2}$ pollution in all three season in all the three land-use areas of Dhulikhel Municipality are with in the permissible limit of NAAQS level of $80 \mu \mathrm{g} / \mathrm{m}^{3}$ of 24 hours standards. The seasonal trend in $\mathrm{NO}_{2}$ levels show that Winter > Pre-monsoon > 
Monsoon. The trend noted among the areas was Commercial > Industrial > Residential on all the occasions.

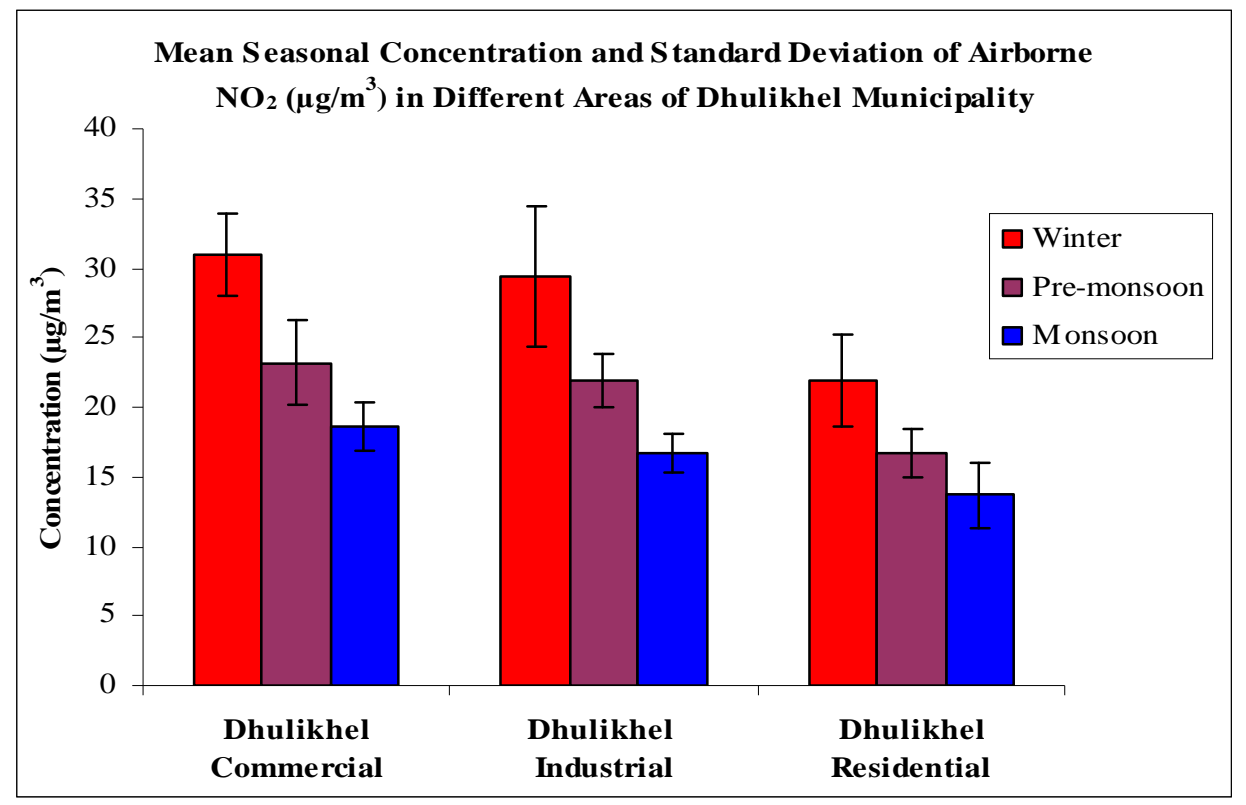

Figure 3. Mean seasonal concentration and standard deviation of airborne $\mathrm{NO}_{2}$ in different areas of Dhulikhel municipality

These findings conclude that, commercial area of Dhulikhel is more defined and is associated with higher $\mathrm{NO}_{2}$ concentration compared to industrial area.

\section{Mean concentration of $\mathrm{NO}_{2}$ in Panauti Municipality}

The seasonal mean values according to commercial, industrial and residential areas of Panauti Municipality are presented in Figure 4. The study found that during winter season the $\mathrm{NO}_{2}$ concentration was more and among the areas Commercial area in Panauti noted highest mean $\mathrm{NO}_{2}$ concentration. The over all mean, standard deviation, minimum and maximum level of $\mathrm{NO}_{2}$ in Panauti was respectively $22.65 \mu \mathrm{g} / \mathrm{m}^{3}, 7.33 \mu \mathrm{g} / \mathrm{m}^{3}, 12.21 \mu \mathrm{g} / \mathrm{m}^{3}$ and $39.55 \mu \mathrm{g} / \mathrm{m}^{3}$. From the table 4 it was also shown that the concentration of mean $\mathrm{NO}_{2}$ pollution in all three season in all the three land-use areas of Panauti municipality are within the permissible limit of NAAQS level of $80 \mu \mathrm{g} / \mathrm{m}^{3}$ for 24 hours standards. 


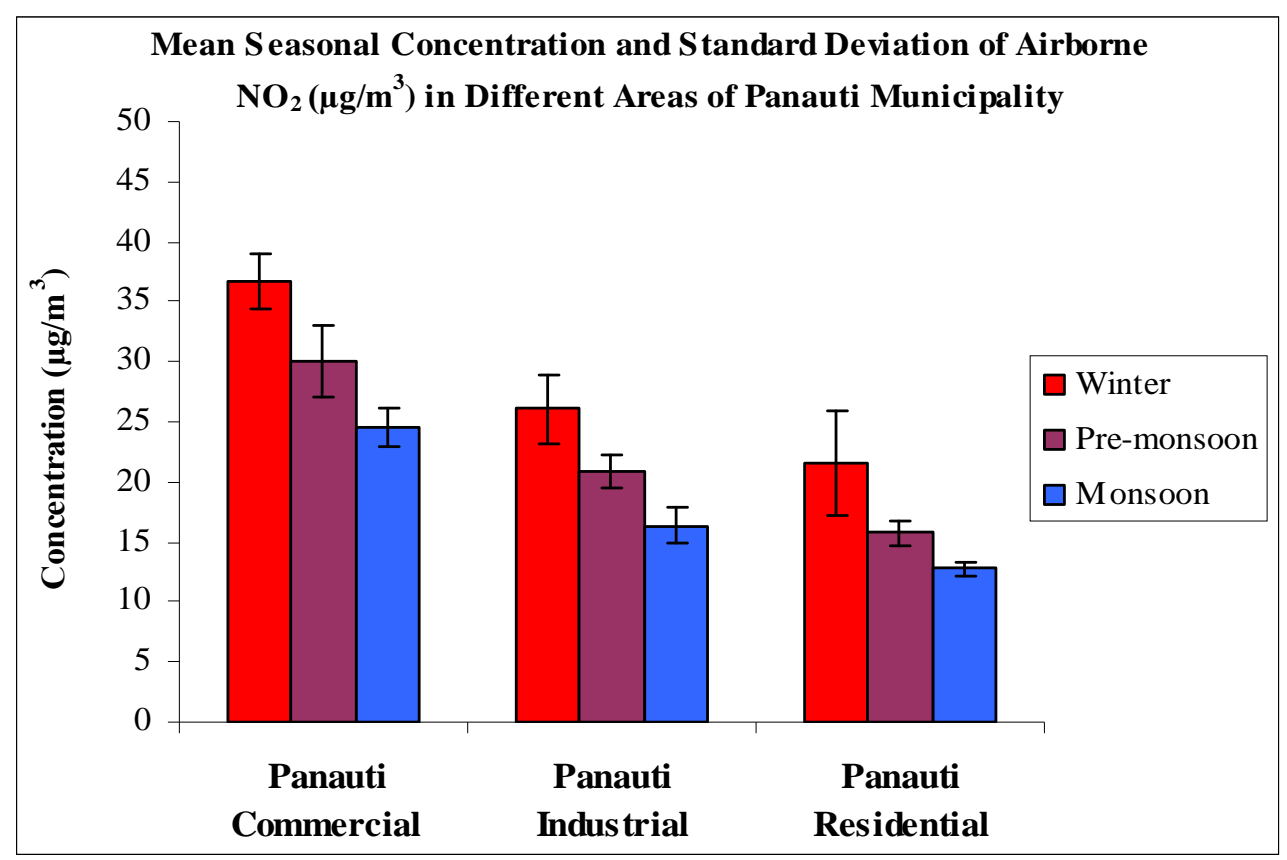

Figure 4. Mean seasonal concentration and standard deviation of airborne $\mathrm{NO}_{2}$ in different areas of Panauti municipality

The seasonal trend in $\mathrm{NO}_{2}$ levels show that Winter $>$ Pre-monsoon $>$ Monsoon. The trend noted among the areas was Commercial > Industrial > Residential on almost all the occasions. This finding suggests that commercial area of Panauti is more defined and is associated with higher $\mathrm{NO}_{2}$ concentration compared to industrial and residential areas.

\section{$\mathrm{NO}_{2}$ concentration in Sites in respect to Seasons}

From the Table 2., it is shown that Banepa commercial area has the highest seasonal mean $\mathrm{NO}_{2}$ concentration with mean concentration of $41.94 \mu \mathrm{g} / \mathrm{m}^{3}$ among all the 9 sites of 3 municipalities. It recorded highest level of concentration all three seasons i.e. winter, pre-monsoon and monsoon. Panauti Residential area has lowest concentration with a mean concentration of $16.55 \mu \mathrm{g} / \mathrm{m}^{3}$.

Table 2. Mean Seasonal Concentration of Airborne $\mathrm{NO}_{2} \mu \mathrm{g} / \mathrm{m}^{3}$ ) in all the Study Areas

\begin{tabular}{|l|c|c|c|c|}
\hline \multicolumn{1}{|c|}{ Sites } & Winter & Pre-monsoon & Monsoon & Seasonal Mean \\
\hline Banepa Commercial & 62.90 & 36.56 & 29.05 & 41.94 \\
\hline Banepa Industrial & 33.90 & 28.54 & 21.70 & 28.12 \\
\hline Banepa Residential & 24.96 & 19.55 & 14.27 & 19.59 \\
\hline Dhulikhel Commercial & 30.98 & 23.18 & 18.56 & 24.09 \\
\hline Dhulikhel Industrial & 29.39 & 21.95 & 16.66 & 22.56 \\
\hline Dhulikhel Residential & 21.86 & 16.72 & 13.66 & 17.31 \\
\hline Panauti Commercial & 36.69 & 29.97 & 24.49 & 30.32 \\
\hline Panauti Industrial & 26.07 & 20.89 & 16.37 & 21.08 \\
\hline Panauti Residential & 21.52 & 15.76 & 12.77 & 16.55 \\
\hline Over all mean & 32.03 & 23.68 & 18.61 & 24.61 \\
\hline
\end{tabular}

The chronology of the highest to lowest pollutant area in all three municipalities are as Banepa Commercial > Panauti Commercial > Banepa Industrial > Dhulikhel Commercial 
> Dhulikhel Industrial > Panauti Industrial > Banepa Residential > Dhulikhel Residential

$>$ Panauti Residential

\section{$\mathrm{NO}_{2}$ concentration in Sites vs Months}

Within seven months among all the nine sites Banepa commercial site recorded the highest concentration of $\mathrm{NO}_{2}$ with a mean level of $41.94 \mu \mathrm{g} / \mathrm{m}^{3}$. Among the seven months all the months it recorded highest $\mathrm{NO}_{2}$ concentration. On the other hand Panauti Residential areas recorded lowest concentration of $\mathrm{NO}_{2}$ pollution with a mean level $16.55 \mu \mathrm{g} / \mathrm{m}^{3}$. Among the seven months all the months it recorded lowest $\mathrm{NO}_{2}$ concentration.

Table 3. Mean Concentration of Airborne $\mathrm{NO}_{2}\left(\mu \mathrm{g} / \mathrm{m}^{3}\right)$ in all the Study Areas According to Months

\begin{tabular}{|l|r|r|r|r|c|c|c|r|}
\hline \multicolumn{1}{|c|}{ Sites } & January & February & March & \multicolumn{1}{c|}{ April } & May & June & July & Average \\
\hline Banepa Commercial & 80.05 & 45.75 & 38.08 & 37.69 & 33.90 & 29.33 & 28.77 & 41.94 \\
\hline Banepa Industrial & 36.28 & 31.53 & 31.47 & 28.24 & 25.90 & 22.46 & 20.94 & 28.12 \\
\hline Banepa Residential & 28.32 & 21.61 & 21.02 & 19.93 & 17.71 & 14.47 & 14.08 & 19.59 \\
\hline $\begin{array}{l}\text { Dhulikhel } \\
\text { Commercial }\end{array}$ & 33.36 & 28.60 & 22.63 & 24.70 & 22.23 & 19.74 & 17.37 & 24.09 \\
\hline Dhulikhel Industrial & 33.52 & 25.26 & 23.86 & 21.96 & 20.02 & 17.53 & 15.79 & 22.56 \\
\hline $\begin{array}{l}\text { Dhulikhel } \\
\text { Residential }\end{array}$ & 24.59 & 19.14 & 18.32 & 16.52 & 15.33 & 14.40 & 12.91 & 17.31 \\
\hline Panauti Commercial & 37.14 & 36.24 & 32.40 & 29.57 & 27.96 & 25.30 & 23.68 & 30.32 \\
\hline Panauti Industrial & 28.56 & 23.59 & 21.88 & 21.36 & 19.44 & 15.83 & 16.90 & 21.08 \\
\hline Panauti Residential & 24.42 & 18.63 & 16.88 & 15.26 & 15.14 & 12.75 & 12.79 & 16.55 \\
\hline Total Average & 36.25 & 27.81 & 25.17 & 23.91 & 21.96 & 19.09 & 18.13 & 24.62 \\
\hline
\end{tabular}

\section{Influence of Meteorological Parameters on $\mathrm{NO}_{2}$ Season VS Meteorological Parameters}

To check the influence of meteorological parameter on $\mathrm{NO}_{2}$ concentration we have selected some meteorological parameter such as Temperature in $\left({ }^{\mathrm{O}} \mathrm{F}\right)$ Fahrenheit, Humidity in Percentage (\%), Dew point in $\left({ }^{\mathrm{O}} \mathrm{F}\right)$ Fahrenheit, Wind speed in MPH, Barometric Pressure in inches, Rainfall in inches and solar radiation in $\mathrm{W} / \mathrm{m}^{2}$, The Table 4 represents the influence of meteorological parameter on $\mathrm{NO}_{2}$ concentration in Banepa Valley.

Table 4. Seasonal $\mathrm{NO}_{2}$ concentration in relation with metrological parameter

\begin{tabular}{|c|c|c|c|c|c|c|c|c|}
\hline Season & $\mathrm{NO}_{2}$ & Temp & Humidity & Dew point & $\begin{array}{l}\text { Wind } \\
\text { Speed }\end{array}$ & $\begin{array}{c}\text { Barometric } \\
\text { Pressure }\end{array}$ & Rainfall & $\begin{array}{c}\text { Solar } \\
\text { Radiation }\end{array}$ \\
\hline Winter & $33.40 \pm 14.32$ & $52.68 \pm 5.61$ & $76.93 \pm 10.99$ & $45.19 \pm 3.90$ & $1.06 \pm 0.41$ & $30.33 \pm 0.08$ & $0.00 \pm 0.01$ & $286.49 \pm 157.39$ \\
\hline $\begin{array}{c}\text { Pre- } \\
\text { monsoon }\end{array}$ & $21.98 \pm 6.10$ & $74.42 \pm 5.60$ & $64.98 \pm 16.47$ & $60.62 \pm 4.33$ & $1.64 \pm 0.75$ & $29.94 \pm 0.12$ & $0.00 \pm 0.00$ & $489.45 \pm 159.61$ \\
\hline Monsoon & $18.41 \pm 5.58$ & $73.62 \pm 4.53$ & $84.53 \pm 14.39$ & $68.06 \pm 3.19$ & $0.74 \pm 0.60$ & $29.76 \pm 0.09$ & $0.00 \pm 0.01$ & $306.35 \pm 150.65$ \\
\hline Total & $26.05 \pm 12.23$ & $64.82 \pm 11.92$ & $74.90 \pm 15.56$ & $55.76 \pm 10.43$ & $1.17 \pm 0.68$ & $30.06 \pm 0.26$ & $0.00 \pm 0.01$ & $357.14 \pm 180.04$ \\
\hline
\end{tabular}

From the table 4. it is observed that when the ambient temperature increases the $\mathrm{NO}_{2}$ concentration decreases. The concentration of $\mathrm{NO}_{2} 33.40 \mu \mathrm{g} / \mathrm{m}^{3}$ was observed in average 
temperature of $52.68{ }^{\mathrm{O}} \mathrm{F}$ and as the average temperature increases to $74.42{ }^{\mathrm{O}} \mathrm{F}$ the $\mathrm{NO}_{2}$ decreases to $21.98 \mu \mathrm{g} / \mathrm{m}^{3}$.

Table 4 also shows, the mean $\mathrm{NO}_{2}$ was found to be lower with increase of relative humidity. The $\mathrm{NO}_{2}$ concentration of $33.40 \mu \mathrm{g} / \mathrm{m}^{3}$ was found in relative humidity of $76.93 \%$ and as this to $84.53 \%$ the $\mathrm{NO}_{2}$ decreases to $18.41 \mu \mathrm{g} / \mathrm{m}^{3}$. This may be due to increase in relative humidity means increase in amount of water vapors in the atmosphere and therefore it can be implied that increase in humidity implies increase in rainfall and which directly decrease the $\mathrm{NO}_{2}$. Table 4 also showed, as the dew point increased the $\mathrm{NO}_{2}$ concentration decreased. The $\mathrm{NO}_{2}$ concentration of $33.40 \mu \mathrm{g} / \mathrm{m}^{3}$ was found when the dew point was $45.19^{\mathrm{O}} \mathrm{F}$ and as the dew point increased in $68.06{ }^{\mathrm{O}} \mathrm{F}$ the $\mathrm{NO}_{2}$ concentration decreased to $18.41 \mu \mathrm{g} / \mathrm{m}^{3}$.

The trend shows that, as the wind speed increases the $\mathrm{NO}_{2}$ decreases. As there is no such clear difference in increased wind speed but the $\mathrm{NO}_{2}$ decreases. The $\mathrm{NO}_{2}$ concentration of $33.40 \mu \mathrm{g} / \mathrm{m}^{3}$ was found in wind speed of $1.06 \mathrm{MPH}$ and as this increase to $1.64 \mathrm{MPH}$ the $\mathrm{NO}_{2}$ decreases to $21.98 \mu \mathrm{g} / \mathrm{m}^{3}$. This means that the wind speed help in decreasing the $\mathrm{NO}_{2}$.

From the Table 4 it is also found that, there is a positive relation with barometric pressure and $\mathrm{NO}_{2}$ concentration. It shows that, in the winter when the barometric pressure was higher (30.33) the $\mathrm{NO}_{2}$ concentration was also higher $\left(33.40 \mu \mathrm{g} / \mathrm{m}^{3}\right)$ and in the monsoon with the decreases of barometric pressure decreased (29.76) there is a decreases trend of $18.41 \mu \mathrm{g} / \mathrm{m}^{3} \mathrm{NO}_{2}$ concentration also observed.

The trend shows that as the rainfall increases the $\mathrm{NO}_{2}$ decreases. From the table 4 , it is seen that $\mathrm{NO}_{2}$ concentration decreases with the increases of rainfall. It is observed that in winter when the mean rainfall was 0.02 inches the mean $\mathrm{NO}_{2}$ was $33.40 \mu \mathrm{g} / \mathrm{m}^{3}$ whereas in monsoon the $\mathrm{NO}_{2}$ comes down in $18.41 \mu \mathrm{g} / \mathrm{m}^{3}$ with the increases of 0.06 inches this may be due the washing effect of the rainfall.

From the table 4 it is observed that, when the solar radiation increases the $\mathrm{NO}_{2}$ concentration decreases. The maximum $\mathrm{NO}_{2}$ concentration $33.40 \mu \mathrm{g} / \mathrm{m}^{3}$ was observed in radiation increases of $286.49 \mathrm{~W} / \mathrm{m}^{2}$. And as the solar radiation increases to $306.35 \mathrm{~W} / \mathrm{m}^{2}$ the $\mathrm{NO}_{2}$ decreases to $18.41 \mu \mathrm{g} / \mathrm{m}^{3}$. This may be due to the increase in temperature as the solar radiation increases.

\section{Time VS Meteorological Parameters}

Table 5. Diurnal $\mathrm{NO}_{2}$ concentration in relation with metrological parameters

\begin{tabular}{|c|c|c|c|c|c|c|c|}
\hline Time & $\mathrm{NO}_{2}$ & Temp & Humidity & Dew point & $\begin{array}{c}\text { Wind } \\
\text { Speed }\end{array}$ & $\begin{array}{c}\text { Barometric } \\
\text { Pressure }\end{array}$ & $\begin{array}{c}\text { Solar } \\
\text { Radiation }\end{array}$ \\
\hline Morning & $26.41 \pm 11.26$ & $63.28 \pm 11.27$ & $79.93 \pm 12.70$ & $56.35 \pm 10.07$ & $1.12 \pm 0.64$ & $30.11 \pm 0.26$ & $422.87 \pm 181.67$ \\
\hline Evening & $25.68 \pm 13.27$ & $66.37 \pm 12.49$ & $69.87 \pm 16.66$ & $55.16 \pm 10.88$ & $1.22 \pm 0.72$ & $30.02 \pm 0.25$ & $291.42 \pm 154.41$ \\
\hline Total & $26.05 \pm 12.23$ & $64.82 \pm 11.92$ & $74.90 \pm 15.56$ & $55.76 \pm 10.43$ & $1.17 \pm 0.68$ & $30.06 \pm 0.26$ & $357.14 \pm 180.04$ \\
\hline
\end{tabular}

The above table represents the diurnal $\mathrm{NO}_{2}$ concentration in relation with metrological parameters. From the table 5, it is observed that in the morning the $\mathrm{NO}_{2}$ concentration is higher then in the evening. And in the evening when the maximum temperature increases 
the $\mathrm{NO}_{2}$ concentration also decreases. The mean $\mathrm{NO}_{2}$ was found to be lower with the decrease of relative humidity. The $\mathrm{NO}_{2}$ concentration of $26.41 \mu \mathrm{g} / \mathrm{m}^{3}$ was found in relative humidity of $79.93 \%$ in the morning and $25.68 \mu \mathrm{g} / \mathrm{m}^{3}$ as this to the decreases of relative humidity to $69.87 \%$.

\section{CONCLUSIONS}

The study provided base line data on air quality in terms of $\mathrm{NO}_{2}$ concentration that provided in representative semi urban areas of Nepal. It represent the mean concentration, standard deviation, maximum and minimum concentration of all nine sites. Influences of meteorological parameters on $\mathrm{NO}_{2}$ were discussed briefly using appropriate table and graphs. Commercial areas in semi urban areas observed with high $\mathrm{NO}_{2}$ levels. $\mathrm{NO}_{2}$ levels had definitive trend at all the three sub-urban areas, like commercial> industrial> residential. Monsoon season was observed less concentration of $\mathrm{NO}_{2}$ in all the areas. A few metrological parameters had inverse relationship with $\mathrm{NO}_{2}$ while few others had direct relationship. It was concluded from the findings of the present study that the $\mathrm{NO}_{2}$ concentration is within the permissible level in Banepa Valley.

\section{ACKNOWLEDGEMENTS}

The authors are thankful to Dr. Roshan Man Bajracharya, Associate Professor who provided useful suggestion through out the research. Sincere thanks to the administration of Kathmandu University for support to carryout the study. Grateful thanks to Department of Environmental Science and Engineering of Kathmandu University providing the equipments and lab facilities.

\section{REFERENCES}

1. Dokiya, Y.,Maruta, E., Yoshikawa, T., Ishimori, H., and Tsurumi, M. (1992), Chemical Species in the Deposition at Some Peaks of the Himalaya, Environ. Sci 5(2), 109-114.

2. Giri D, Krishna Murthy V, Adhikary P R, Chhetri R B, Khanal S N, Sharma C K, (2004), "Descriptive Statistical Analysis of $\mathrm{PM}_{10}$ Values in Selected Air Monitoring Sites in Kathmandu Valley”, Paper Presented in RONAST, Nepal

3. Rao, M.N. and Rao, H.V.N., (1994), "Air Pollution" , Tata Mcgraw- Hill Publishing Company Ltd., New Delhi, India

4. Sharma, B. K., Sharma, A. P., and Pokharel, A. (1995), Air Pollution and its E.ect on Respiratory Diseases in Kathmandu, Nepal J. Sci. and Tech. 1, 115-122.

5. Shrestha, A. B., Wake, C. P., and Dibb, J. E. (1997), Chemical Composition of Aerosol and Snow in the High Himalaya during the Summer Monsoon Season, Atmos. Environ. 31, 2815-2826.

6. Thapa Aun, (2001), "Study of Indoor vs. Outdoor Air Microflora and its Relation to PM 7.07”, Central Department of Microbiology, Tribhuwan University, Nepal 
KATHMANDU UNIVERSITY JOURNAL OF SCIENCE, ENGINEERING AND TECHNOLOGY

VOL. I, No. V, SEPTEMBER 2008, pp 1-11.

7. URBAIR, (1997), Urban Air Quality Management Strategy in Asia: Kathmandu Valley Report. The World Bank Technical Paper No. 378, Washington D.C., USA, $155 \mathrm{pp}$. 